\title{
The Relationship between Service Quality and Hajj's Applicant Satisfaction Study: The Administration Process, Banyumas Regency
}

\author{
Ricky Bayu Robbany ${ }^{\text {* }}$ \\ ${ }^{a}$ Ministry of Religious Affairs Office, Banyumas Regency, Central Java, Indonesia
}

\section{INFORMASI ARTIKEL}

Article history:

Data Submission: 29 August 2018

First Revision: 10 September 2018

Accepted: 07 December 2018

Available online: 17 December 2018

Keywords: hajj application, service quality, applicant satisfaction

\begin{abstract}
Hajj is an annual Islamic pilgrimage to Mecca, the holiest city for Moslems. The purpose of this research is to examine the relationship between service quality and Hajj applicant's satisfaction. The research shows that service quality have a positive influence with the satisfaction. Applicant believes that among the five factors in service quality, namely tangible, reliability, empathy, and assurance (the highest) have good results while responsiveness requires to be improved. Consumers hope that the government will improve the service on Hajj application and its introduce a new, as least method to increase satisfaction.
\end{abstract}

\section{INTISARI}

Haji adalah ziarah tahunan Islam ke Mekkah, kota paling suci bagi umat Islam. Tujuan dari penelitian ini adalah untuk menguji hubungan antara kualitas layanan dan kepuasan pendaftar haji. Hasil penelitian menunjukkan bahwa kualitas layanan memiliki pengaruh positif terhadap kepuasan. Pendaftar percaya bahwa di antara lima faktor dalam kualitas layanan, yaitu tangible, keandalan, empati, dan jaminan (yang tertinggi) memiliki hasil yang baik sementara responsiveness perlu ditingkatkan. Konsumen berharap bahwa pemerintah akan meningkatkan layanan pada pendaftaran Haji dan memperkenalkan sesuatu yang baru, paling tidak sebagai metode untuk meningkatkan kepuasan.

2018 FIA UB. All rights reserved.

\section{Introduction}

Hajj is an annual Islamic pilgrimage to Mecca, the holiest city for Moslems. It is performed in a specific period; from the 8th to the 13th of the last month (Dhul-Hijja) according to the hegira calendar. Furthermore, Hajj is a visit to the House in Makkah (Baitullah) to perform Tawaf (around the Kaaba 7 times), sa'i (Journey of marwah to safa hill seven times) and wukuf (the standing at Arafat) and other practices with the intention of Hajj in a certain period to achieve the blessings of God. Hajj's law is mandatory for at least once in one's life time (meet pillars of Islam), and for those who vow, as well as for those who had already pilgrimage sunnah (not mandatory). This has made Hajj a multi-billion-dollar business since with hundreds of thousands of travelers each year the need for transportation (bus and airplane), food catering, hotel, etc. in-home country and in Saudi Arabia is required. 
The Hajj event in Moslem life is increasingly being viewed in both national and international society. Approximately 3 million Muslims around the world from 183 countries and every country has have quota to fill the obligation to visit the holy land. The quota numbers are different for each country, depending on the Kingdom Saudi Arabia and each person is obliged to pay and wait for approval to undertake the Hajj. Any failure or unreliability in Hajj service could cause irreversible and permanent harm to faithful Muslims.

Many pilgrims encounter many service problems when carrying out the application process and while on Hajj too such as use of dilapidated buses and the catering service in Saudi Arabia. Because of the service problems that arise in the implementation of Hajj deriving from the public when performing worship, it is necessary to improve the quality of service to improve the satisfaction of the pilgrims. Departing from the above issues here, a service management system is required that prioritizes customers' satisfaction.

In recent years, awareness of Muslims to carry out the Hajj continues to increase. On the one hand this is very encouraging. The development of good service in fact will lead to the satisfaction of those who receive services. During this time the Government of Indonesia (MoRA here) becomes the sole organizer of the Hajj services or in economic terms is often referred to as the monopoly market holder with no market competitors. Several years experienced ups and downs. This fluctuation can be seen from the number of registrations starting from 2013-2017 and viewed from the following data sources:

Table 1 Number of Pilgrim Applicants in Banyumas District

\begin{tabular}{|c|c|c|c|c|}
\hline No. & Year & Male & Female & Total Amount \\
\hline 1 & 2013 & 1,286 & 1,484 & 2,770 \\
\hline 2 & 2014 & 1,184 & 1,336 & 2,520 \\
\hline 3 & 2015 & 1,302 & 1,467 & 2,769 \\
\hline 4 & 2016 & 1,524 & 1,338 & 2,862 \\
\hline 5 & $2017^{*}$ & 574 & 539 & 1113 \\
\hline
\end{tabular}

Source: Ministry of Religious Affairs Office, Banyumas Regency, 2017

* Until May 2017

Table 2 Hajj Quota in Banyumas Residency 2017

\begin{tabular}{|l|l|c|}
\hline No & \multicolumn{1}{|c|}{ District } & Number (people) \\
\hline 1 & Cilacap & 1,024 \\
\hline 2 & Banyumas & 1,113 \\
\hline 3 & Purbalingga & 692 \\
\hline 4 & Banjarnegara & 723 \\
\hline
\end{tabular}

Source: Ministry of Religious Affairs Office, Banyumas Regency, 2017
As the sole Hajj operator in Indonesia, in a developing country where public services are not that good yet generally, MoRA seeks to realize the satisfaction of self-organizing Hajj pilgrims during the process, both in the homeland and in Saudi Arabia. The satisfaction index of Indonesian pilgrims to the Hajj service in year $1435 \mathrm{H}$ (2014 CE) decreased compared to the previous year's Hajj's. In general, the service of Hajj in 2014 is recorded with an index of $81.52 \%$, but it decreased $1.17 \%$ from the previous year (2013), and even in the following year increased to $82.67 \%$ and 83.83\%, respectively in 2015 and 2016 (Basyir, 2018). Changes in the Central Bureau of Statistics data was influenced by a decrease in transport services, non-fleet personnel, and accommodation or lodgings. Accommodation and transport occupy the lowest rank in the index of satisfaction of pilgrims in 2014.

The following studies have been carried out in several developing countries regarding an instrument for measuring Hajj service quality. First, a study by Hafid \& Tahmir (2016) tested Hajj Service Management at the Department of Religious Affairs in Gowa Regency (Indonesia), published by MCSER Publishing, Rome-Italy (2016).

Second, a study by Naceur Jabnoun (2003) shows that instruments could be used for research purposes in the Hajj industry, such as grant regulation, license extension or cancellations by Hajj agent and for assessing their performance. Third, Eid (2012) also has attempted to develop a framework for reaching the high quality of religious tourism marketing in case of Hajj service in Saudi Arabia.

The purpose of this study is to examine the relationship between service quality and customer satisfaction in the public sector (Hajj), and to identify the highest factor in service quality related to the customer satisfaction. The results will be eventually used to make suggestions for policy makers to increase the satisfaction and service quality of the Hajj. Thus, the objective of this research is to identify the problems of service quality in Indonesia in general and Hajj in particular and find solutions to improve the satisfaction of applicants.

This study is an empirical research task with a quantitative approach. To answer the study objectives, this study uses the quantitative method by presenting the data, which will then be analyzed through correlation analysis and a descriptive analysis to explain the results. The data collected is secondary data from reliable sources and supporting data obtained by surveys. 


\section{Theory}

\subsection{Concept of Service}

Benkenstein et al (2003) concludes that leisure service with satisfaction is a function of cognitive and emotional (psychological) factors. Another opinion about the service according to Gronross cited by Ratminto and Atik Septi Winarsih (2006), service is an activity or series of activities that are invisible (intangible) that occur because of the interaction between customers and employees or things others provided that are meant to be solved weeks in advance for customers/ customers.

In the scope of the government bureaucracy, the role of service has a greater influence because of public interest that it directly involves the state apparatus which has a duty to provide the public at the best level. Providing services to the public is one of the efforts of the Government for ensuring good governance. Therefore, a good service to the public (community) is not negotiable. Service could be an invisible that include people efforts and equipment.

Based on the understanding of the above, it can be concluded that service is a series of activities/ events visible because of the interaction between customers as users of services by the service providers with the aim of providing/ giving satisfaction to the customer and not tied to the sale of a product or other services.

\subsection{Service Quality}

Grönroos (1984) built a model consisting of the three dimensions, namely technical quality, functional quality, and corporate image, which effectively consider the service outcome component when measuring the quality of a service. Technical quality describes how the customer obtains the service and functional quality describes the service achieved in the end. Meanwhile, corporate image influences the perception of quality in a positive, neutral, or negative manner.

Efforts to implement quality of service can be through the concept of excellent service. In effect excellent service starts as the efforts of the businesses to provide the best service. MoRA reorganized that from a service of covering various types of services, having no relevance to each other and through several doors, into the pattern of a one-stop service where the service is held in one place and includes various types of services that have relevance to the process and serviced through a single door.

\subsection{Dimensions of Service Quality}

At a later stage, Parasuraman et al, (1988) concludes that there are five dimensions of ServQual (Service Quality), which is used to measure the quality of services, namely:

a) Tangibles, or physical evidence: the ability of a company to demonstrate its existence to external parties; appearance and abilities of physical infrastructure companies and the state of the surrounding environment as tangible proof of the services provided by the service provider;

b) Reliability: the ability of companies to provide services as promised accurate and reliable;

c) Responsiveness: willingness to help and provide fast service (responsiveness) and the right of the customer to be provided clear information;

d) Assurance, or guarantees and assurances that knowledge, politeness: the ability of the company's employees to gain confidence of the customers to the company; and

e) Empathy: gives genuine concern to the individual or individuals by striving to understand the desires of customers.

Public services should always change to follow the development of society, because society is dynamic. In this case the government should negotiate and collaborate the range of community interest. So, the public services have the appropriate quality expected by society. Public services are carried out in an integrated series of activities that are simple, transparent, smooth, accurate, complete, fair, and affordable. To be able to provide satisfactory services for service users, service delivery must meet the concept of service. The concept of service quality is a factor that reflects customer perceptions and votes against the five specific dimensions performance of the service.

\subsection{Public Satisfaction}

In the enterprise/ organization engaged in service, customers are people who use services. Customers are people who receive the work of someone/ organization. It is they who determine what kind of quality, and only the customers who convey what and how their needs are met are part of this equation.

In this modern era, where the business competition is ever more competitive, the goals of the organization is not only to defend the existing customers, but also to gain new customers by improving service or products to attract those newer, potential customers to buy or use the product or service and thereby cause the existing customers to be more loyal to the product or service in the future.

Based on the figure above shows that when public organizations give service, then the purpose of the organization is translated in the form of an actual service that will have value for customers. On the other hand customers have needs and desires embodied in 
expectations for the product. If both of these interests (organizations and customers) were able to see the meeting point it will manifest in self-satisfaction of customers. Because that required the similarity between the needs of customers with the products issued by the organization. Product service is of course adjusted to the organization's goals. Organizations need to identify customers, internal customers or external customers; business customers or end customers. Meanwhile, customer satisfaction is achieved when the needs, desires, and expectations of customers are met.

The quality gap is important, it is caused by final customer rating of what is expected compared to what is received. The quality is identified in five gaps (Kotler and Keller, 2007):

a) The gap between customer expectations with management perceptions;

b) The gap between the perception of the quality of management specifications and services required;

c) The gap between the specifications of quality of service with the delivery of services;

d) The gap between the deliveries of services with external communications on customers; and

e) The gap between the perception of the services and services expected.

The differences between actual performance and customer perception of the service. This gap occurs when the customer has a wrong perception of the quality of these services.

\subsection{Relationship Between Service Quality to Consumer Satisfaction}

According to Cronin \& Taylor (1992) it is in line with the fact that service quality is a determinant of customer satisfaction, because service quality comes from outcome of the services from service providers in organizations.

The conclusion of the above theories that states the relationship between customer satisfaction with quality is customer satisfaction relate to several aspects of one of the quality of service and is closely related to quality, because the quality is a benchmark and index of consumer satisfaction. The literature review shows latest researches up to 2011 on the relationship between customer satisfaction and service quality. The researches in this area have been covered so far as below;

a) It has been researched that there is a relationship between customer satisfaction and service quality;

b) It has been researched that service quality could be evaluated with the use of SERVQUAL model;

c) It has been researched that service quality could be evaluated by other dimensions of service quality that is, functional and technical and not necessarily SERVQUAL model; and

d) Some researchers even tested service quality and service quality dimensions.

\section{Research Method}

This research uses the quantitative method analysis to address research questions. The quantitative method is one of research methods that emphasize statistical analysis to test specific theories by examining the relationship between variables (Cresswell, 2014).

The approach used in this study is to analyze data of the original survey. Survey research includes quantitative research to examine the behavior of an individual or group. In general, survey research here uses questionnaires as data collection tools. Survey research is a study that takes samples from a population and uses a questionnaire as a basic data retrieval tool (Hasibuan, 2007). The unit of analysis in the study is pilgrim applicants in Ministry of Religious Affairs (MoRA) located in Banyumas Regency. Additionally, supporting data obtained by secondary data from the Central Bureau of Statistics (BPS), MoRA, as well as other related institutions. The conceptual model for this research:

SERVICE QUALITY

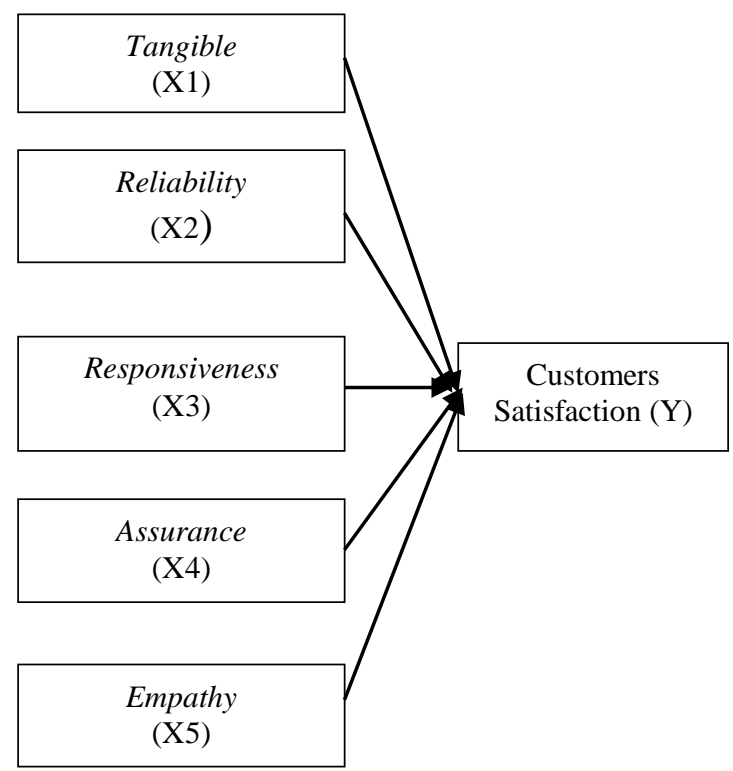

Figure 1 Conceptual Model of Research

Source: Analytical result, 2017

\section{Results and Discussion}

\subsection{Results}

To further clarify the description of the research subjects and to further strengthen the analysis of the 
research results it is necessary to describe in advance the general overview of research respondents. The size of sample is 95 pilgrims and represents the major demographic characteristics of the respondents. Discussion of the identity of these respondents is divided into several sections. For respondent's characteristics by age can be seen in Table 3 :

Tabel 3 Characteristics of Respondents by Age

\begin{tabular}{|c|c|c|c|}
\hline No. & $\begin{array}{c}\text { Age } \\
\text { (years) }\end{array}$ & $\begin{array}{c}\text { Number of } \\
\text { Travelers }\end{array}$ & Percentage (\%) \\
\hline 1 & $20-40$ & 85 & 38.0 \\
\hline 2 & $41-60$ & 108 & 48.5 \\
\hline 3 & $>61$ & 30 & 13.5 \\
\hline \multicolumn{2}{|c|}{ Total } & 223 & 100.0 \\
\hline
\end{tabular}

Source: Analytical result, 2017

Based on the Table 3 above, most of the Hajj applicants aged are between 41-60 years or $48.5 \%$. For ages 60 and older and less than 40 years old, were $13.5 \%$ and $38 \%$, respectively.

Characteristics of respondents are differentiated by gender as can be seen in Table 4:

Tabel 4 Characteristics of Respondents by Gender

\begin{tabular}{|c|l|c|c|}
\hline No. & Gender & $\begin{array}{c}\text { Number of } \\
\text { Travelers }\end{array}$ & Percentage (\%) \\
\hline 1 & Male & 103 & 46.2 \\
\hline 2 & Female & 120 & 53.8 \\
\hline \multicolumn{2}{|c|}{ Total } & 223 & 100.0 \\
\hline
\end{tabular}

Source: Analytical result, 2017

Table 4 indicates that most of the pilgrim's respondents of the study are female $53.8 \%$, while $46.2 \%$ of other respondents are male.

The characteristics of respondents based on most recent education is presented in Table 5:

Tabel 5 Most Recent Education Level of Respondents

\begin{tabular}{|c|l|c|c|}
\hline No. & $\begin{array}{c}\text { Elementary/ Junior } \\
\text { High School }\end{array}$ & $\begin{array}{c}\text { Number of } \\
\text { Respondents }\end{array}$ & $\begin{array}{c}\text { Percentage } \\
(\%)\end{array}$ \\
\hline 1 & $\begin{array}{l}\text { Elementary/Junior } \\
\text { High School }\end{array}$ & 76 & 34.0 \\
\hline 2 & Senior High School & 48 & 21.5 \\
\hline 3 & Diploma & 16 & 7.2 \\
\hline 4 & Bachelor & 72 & 32.3 \\
\hline 5 & Postgraduate & 11 & 4.9 \\
\hline \multicolumn{2}{|c|}{ Total } & 223 & 100.0 \\
\hline
\end{tabular}

Source: Analytical result, 2017

By Table 5 it seems that most of the pilgrim respondents have an elementary/junior high school education background (34\%) followed by a Bachelor of Education (32.3\%), the Senior High School education (21.5\%) and a Diploma level of education at $7.2 \%$, and the smallest number hold a postgraduate diploma at $4.9 \%$.

Pilgrim's respondent is categorized based on the profession:
Tabel 6 Characteristics of Respondents Based on Type of Employment

\begin{tabular}{|c|l|c|c|}
\hline No. & $\begin{array}{c}\text { Type of } \\
\text { Employment }\end{array}$ & $\begin{array}{c}\text { Number of } \\
\text { Respondents }\end{array}$ & $\begin{array}{c}\text { Percentage } \\
(\%)\end{array}$ \\
\hline 1 & Entrepreneurship & 85 & 38.0 \\
\hline 2 & Army / Police & 6 & 2.7 \\
\hline 3 & $\begin{array}{l}\text { Pensionary and } \\
\text { Others }\end{array}$ & 70 & 31.4 \\
\hline 4 & $\begin{array}{l}\text { Farmers / } \\
\text { Fishermen }\end{array}$ & 22 & 9.8 \\
\hline 5 & $\begin{array}{l}\text { Civil Servants / } \\
\text { State enterprises }\end{array}$ & 40 & 18.0 \\
\hline \multicolumn{2}{|c|}{ Total } & 223 & 100.0 \\
\hline
\end{tabular}

Source: Analytical result, 2017

We can understand by Table 6 that most of the applicants are entrepreneurship, making up 38\%, followed by pensionary and others at $31.4 \%$, civil servants/ state enterprises at $18 \%$, Farmers/ fishermen at $9.8 \%$ and the least army/ police background as only $2.7 \%$ of respondents.

Tabel 7 Tangible

\begin{tabular}{|c|c|c|c|}
\hline No. & Question & Answer & $\begin{array}{c}\text { Percentage } \\
(\%)\end{array}$ \\
\hline \multirow[t]{5}{*}{1} & \multirow{5}{*}{$\begin{array}{l}\text { Hajj organizers } \\
\text { have complete } \\
\text { Hajj } \\
\text { service } \\
\text { facilities } \\
\text { and } \\
\text { infrastructure }\end{array}$} & Strongly Agree & 46.4 \\
\hline & & Agree & 39.1 \\
\hline & & Neutral & 10.2 \\
\hline & & Disagree & 1.5 \\
\hline & & Strongly Disagree & 2.9 \\
\hline \multirow[t]{5}{*}{2} & \multirow{5}{*}{$\begin{array}{l}\text { Hajj } \\
\text { infrastructures } \\
\text { is adequate }\end{array}$} & Strongly Agree & 37.7 \\
\hline & & Agree & 47.8 \\
\hline & & Neutral & 11.6 \\
\hline & & Disagree & 0 \\
\hline & & Strongly Disagree & 2.9 \\
\hline \multirow[t]{5}{*}{3} & \multirow{5}{*}{$\begin{array}{l}\text { Room of the } \\
\text { organizers } \\
\text { are spacious, } \\
\text { clean and } \\
\text { comfortable }\end{array}$} & Strongly Agree & 30.4 \\
\hline & & Agree & 36.2 \\
\hline & & Neutral & 27.5 \\
\hline & & Disagree & 2.9 \\
\hline & & Strongly Disagree & 2.9 \\
\hline \multirow[t]{5}{*}{4} & \multirow{5}{*}{$\begin{array}{l}\text { Room service is } \\
\text { adequate in } \\
\text { supporting } \\
\text { services }\end{array}$} & Strongly Agree & 30.4 \\
\hline & & Agree & 33.3 \\
\hline & & Neutral & 30.4 \\
\hline & & Disagree & 2.9 \\
\hline & & Strongly Disagree & 2.9 \\
\hline \multirow[t]{5}{*}{5} & \multirow{5}{*}{$\begin{array}{l}\text { Appearance of } \\
\text { neat } \\
\text { employees in } \\
\text { serving }\end{array}$} & Strongly Agree & 50.7 \\
\hline & & Agree & 40.6 \\
\hline & & Neutral & 4.3 \\
\hline & & Disagree & 1.5 \\
\hline & & Strongly Disagree & 2.9 \\
\hline
\end{tabular}

Source: Ministry of Religious Affairs Office, Banyumas Regency, 2017

Table 7 shows the result of "Tangible". 46.4\% of the respondents recognize the completeness of the Hajj service facilities and infrastructure. This group also agreed to the adequacy of Hajj infrastructure (47.8\%), 
that the room where the organizers hold explanatory meets is spacious, clean and comfortable $(36.2 \%)$, but there are still $27.5 \%$ whom were not satisfied/ feel the rooms are average arrangements.

\begin{tabular}{|c|c|c|c|}
\hline No. & Question & Answer & $\begin{array}{c}\text { Percentage } \\
(\%)\end{array}$ \\
\hline \multirow[t]{5}{*}{1} & \multirow{5}{*}{$\begin{array}{l}\text { Existence of } \\
\text { guidance for } \\
\text { pilgrim } \\
\text { services }\end{array}$} & Strongly Agree & 50.7 \\
\hline & & Agree & 30.4 \\
\hline & & Neutral & 13 \\
\hline & & Disagree & 4.3 \\
\hline & & Strongly Disagree & 1.5 \\
\hline \multirow[t]{5}{*}{2} & \multirow{5}{*}{$\begin{array}{l}\text { Hajj services } \\
\text { schedule } \\
\text { according } \\
\text { to the rules }\end{array}$} & Strongly Agree & 50.7 \\
\hline & & Agree & 40 \\
\hline & & Neutral & 5.8 \\
\hline & & Disagree & 0 \\
\hline & & Strongly Disagree & 2.9 \\
\hline \multirow[t]{5}{*}{3} & \multirow{5}{*}{$\begin{array}{l}\text { There are } \\
\text { efforts to } \\
\text { keep the } \\
\text { service } \\
\text { environment } \\
\text { clean and neat }\end{array}$} & Strongly Agree & 34.8 \\
\hline & & Agree & 39.1 \\
\hline & & Neutral & 21.7 \\
\hline & & Disagree & 0 \\
\hline & & Strongly Disagree & 4.3 \\
\hline \multirow[t]{5}{*}{4} & \multirow{5}{*}{$\begin{array}{l}\text { Same service } \\
\text { for pilgrims } \\
\text { without } \\
\text { error }\end{array}$} & Strongly Agree & 26 \\
\hline & & Agree & 53.6 \\
\hline & & Neutral & 15.9 \\
\hline & & Disagree & 1.4 \\
\hline & & Strongly Disagree & 2.9 \\
\hline \multirow[t]{5}{*}{5} & \multirow{5}{*}{$\begin{array}{l}\text { Sympathetic } \\
\text { attitude of } \\
\text { employees } \\
\text { when } \\
\text { serving }\end{array}$} & Strongly Agree & 62.1 \\
\hline & & Agree & 39.1 \\
\hline & & Neutral & 4.3 \\
\hline & & Disagree & 1.4 \\
\hline & & Strongly Disagree & 2.9 \\
\hline
\end{tabular}

Source: Ministry of Religious Affairs Office, Banyumas Regency, 2017

Table 8 presents the results of "Reliability", where guidance for pilgrim services is recognized as strongly agreeing by $50.7 \%$. There are three big different points of view in the respondents to keep the service environment clean and neat. One group totaling 34.8\% thinks that the service environment is clean and neat and very good. While $39.1 \%$ responded that the facilities and employees were clean, neat and good. The other $21.7 \%$ do not feel whether the area was clean and neat are issues importance or not because most do not care about the matter. This group of applicants' usually focuses on their registration process.

Tabel 9 Responsiveness

\begin{tabular}{|c|l|l|c|}
\hline \multirow{2}{*}{ No. } & \multicolumn{1}{|c|}{ Question } & \multicolumn{1}{|c|}{ Answer } & $\begin{array}{c}\text { Percentage } \\
(\%)\end{array}$ \\
\hline 1 & \multirow{2}{*}{$\begin{array}{l}\text { Speed of } \\
\text { registration } \\
\text { procedure and } \\
\text { service }\end{array}$} & Strongly Agree & 42.0 \\
\cline { 3 - 4 } & & Agree & 43.5 \\
\cline { 3 - 4 } & Neutral & 11.6 \\
\cline { 3 - 4 } & Disagree & 1.4 \\
\cline { 3 - 4 } & Strongly Disagree & 1.4 \\
\hline 2 & A detailed & Strongly Agree & 34.8 \\
\cline { 2 - 4 } & & \multicolumn{2}{|l}{} \\
\hline
\end{tabular}

\begin{tabular}{|c|c|c|c|}
\hline No. & Question & Answer & $\begin{array}{c}\text { Percentage } \\
(\%)\end{array}$ \\
\hline & \multirow{4}{*}{$\begin{array}{l}\text { explanation } \\
\text { process of } \\
\text { registration and } \\
\text { Hajj } \\
\text { implementation }\end{array}$} & Agree & 49.2 \\
\hline & & Neutral & 13.0 \\
\hline & & Disagree & 0.0 \\
\hline & & Strongly Disagree & 2.9 \\
\hline \multirow[t]{5}{*}{3} & \multirow{5}{*}{$\begin{array}{l}\text { The ability of the } \\
\text { organizers to } \\
\text { serve the needs of } \\
\text { pilgrims quickly } \\
\text { and precisely }\end{array}$} & Strongly Agree & 36.2 \\
\hline & & Agree & 50.7 \\
\hline & & Neutral & 10.0 \\
\hline & & Disagree & 1.4 \\
\hline & & Strongly Disagree & 1.4 \\
\hline \multirow[t]{5}{*}{4} & \multirow{5}{*}{$\begin{array}{l}\text { The ability to } \\
\text { respond to } \\
\text { problems arising } \\
\text { from pilgrims }\end{array}$} & Strongly Agree & 33.3 \\
\hline & & Agree & 50.7 \\
\hline & & Neutral & 13.0 \\
\hline & & Disagree & 0.0 \\
\hline & & Strongly Disagree & 2.9 \\
\hline \multirow[t]{5}{*}{5} & \multirow{5}{*}{$\begin{array}{l}\text { Responding to the } \\
\text { needs of pilgrims } \\
\text { appropriately }\end{array}$} & Strongly Agree & 27.5 \\
\hline & & Agree & 55.0 \\
\hline & & Neutral & 13.0 \\
\hline & & Disagree & 2.9 \\
\hline & & Strongly & 1.4 \\
\hline
\end{tabular}

Source: Ministry of Religious Affairs Office, Banyumas Regency, 2017

Table 9 reveals the result of "Responsiveness" in the applicants. In preparing the speed of registration procedure and service, $42.0 \%$ of the respondents believe that it was at a very good level and $43.8 \%$ feel the service just at the good level. Then, the ability of employees to serve the needs of pilgrims quickly and precisely, the majority remains at a good level (50.7\%) and only $36.2 \%$ applicants feel strongly satisfied with it.

Tabel 10 Assurance

\begin{tabular}{|c|c|c|c|}
\hline No. & Question & Answer & $\begin{array}{l}\text { Percentage } \\
(\%)\end{array}$ \\
\hline \multirow[t]{5}{*}{1} & \multirow{5}{*}{$\begin{array}{l}\text { There is enough } \\
\text { time from the } \\
\text { employees to } \\
\text { attend to the } \\
\text { pilgrims }\end{array}$} & Strongly Agree & 37.7 \\
\hline & & Agree & 52.2 \\
\hline & & Neutral & 13.0 \\
\hline & & Disagree & 2.9 \\
\hline & & Strongly Disagree & 1.4 \\
\hline \multirow[t]{5}{*}{2} & \multirow{5}{*}{$\begin{array}{l}\text { Employees can } \\
\text { explain in detail } \\
\text { about the } \\
\text { process to be } \\
\text { followed until } \\
\text { the completion } \\
\text { of the } \\
\text { pilgrimage }\end{array}$} & Strongly Agree & 46.4 \\
\hline & & Agree & 40.6 \\
\hline & & Neutral & 10.1 \\
\hline & & Disagree & 0.0 \\
\hline & & Strongly Disagree & 2.9 \\
\hline \multirow[t]{5}{*}{3} & \multirow{5}{*}{$\begin{array}{l}\text { Guarantee } \\
\text { service for Hajj } \\
\text { pilgrims }\end{array}$} & Strongly Agree & 44.9 \\
\hline & & Agree & 43.5 \\
\hline & & Neutral & 8.7 \\
\hline & & Disagree & 0.0 \\
\hline & & Strongly Disagree & 2.9 \\
\hline \multirow[t]{2}{*}{4} & \multirow{2}{*}{$\begin{array}{l}\text { Employees } \\
\text { knowledge, }\end{array}$} & Strongly Agree & 44.9 \\
\hline & & Agree & 43.5 \\
\hline
\end{tabular}




\begin{tabular}{|c|l|l|c|}
\hline \multirow{2}{*}{ No. } & \multicolumn{1}{|c|}{ Question } & \multicolumn{1}{|c|}{ Answer } & $\begin{array}{c}\text { Percentage } \\
(\%)\end{array}$ \\
\hline \multirow{2}{*}{$\begin{array}{l}\text { friendliness, } \\
\text { courtesy, and } \\
\text { the ability to } \\
\text { work } \\
\text { professionally }\end{array}$} & Neutral & Disagree & 0.7 \\
\cline { 3 - 4 } & $\begin{array}{l}\text { Strongly Disagree } \\
\text { Courteous } \\
\text { service from } \\
\text { employees }\end{array}$ & Strongly Agree & 2.9 \\
\cline { 3 - 4 } & \begin{tabular}{l} 
Agree \\
\cline { 3 - 4 }
\end{tabular} & Neutral & 52.2 \\
\cline { 3 - 4 } & Disagree & 1.0 .1 \\
\cline { 3 - 4 } & & Strongly Disagree & 1.5 \\
\hline
\end{tabular}

Source: Ministry of Religious Affairs Office, Banyumas Regency, 2017

Table 11 shows the result of "Empathy". Most residents in the Banyumas Regency where the research was conducted appreciate the time allowed by the employees to serve the pilgrims thus rating to $52.2 \%$ and another $37.7 \%$ felt that the service was more than adequate. Next, Employees explained the process and guarantee the service to reach the high value from respondents (46.4\% and 45\%). Last, kinship and professionality from employees also obtained high ratings but there are still respondents that just feel that the service is ordinary $(8.7 \%$ and $10.1 \%)$.

Tabel 11 Empathy

\begin{tabular}{|c|c|c|c|}
\hline No. & Question & Answer & $\begin{array}{c}\text { Percentage } \\
(\%)\end{array}$ \\
\hline \multirow[t]{5}{*}{1} & \multirow{5}{*}{$\begin{array}{l}\text { Provide } \\
\text { convenience for } \\
\text { pilgrims to get } \\
\text { services }\end{array}$} & Strongly Agree & 55.0 \\
\hline & & Agree & 34.3 \\
\hline & & Neutral & 14.5 \\
\hline & & Disagree & 0.0 \\
\hline & & $\begin{array}{l}\text { Strongly } \\
\text { Disagree }\end{array}$ & 0.0 \\
\hline \multirow[t]{5}{*}{2} & \multirow{5}{*}{$\begin{array}{l}\text { Serve and give } \\
\text { special attention } \\
\text { with sincerity and } \\
\text { full of } \\
\text { responsibility }\end{array}$} & Strongly Agree & 44.9 \\
\hline & & Agree & 47.8 \\
\hline & & Neutral & 4.3 \\
\hline & & Disagree & 0.0 \\
\hline & & $\begin{array}{l}\text { Strongly } \\
\text { Disagree }\end{array}$ & 2.9 \\
\hline \multirow[t]{5}{*}{3} & \multirow{5}{*}{$\begin{array}{l}\text { Employee } \\
\text { concerns about } \\
\text { the problems } \\
\text { faced by pilgrims }\end{array}$} & Strongly Agree & 47.8 \\
\hline & & Agree & 42.0 \\
\hline & & Neutral & 7.2 \\
\hline & & Disagree & 0.0 \\
\hline & & $\begin{array}{c}\text { Strongly } \\
\text { Disagree }\end{array}$ & 2.9 \\
\hline \multirow[t]{5}{*}{4} & \multirow{5}{*}{$\begin{array}{l}\text { Understand and } \\
\text { provide aid as } \\
\text { needed }\end{array}$} & Strongly Agree & 43.5 \\
\hline & & Agree & 44.9 \\
\hline & & Neutral & 8.7 \\
\hline & & Disagree & 0.0 \\
\hline & & $\begin{array}{c}\text { Strongly } \\
\text { Disagree }\end{array}$ & 2.9 \\
\hline \multirow[t]{4}{*}{5} & \multirow{4}{*}{$\begin{array}{l}\text { Employees strive } \\
\text { to give their best }\end{array}$} & Strongly Agree & 50.7 \\
\hline & & Agree & 36.2 \\
\hline & & Neutral & 8.7 \\
\hline & & Disagree & 1.5 \\
\hline
\end{tabular}

\begin{tabular}{|c|c|l|c|}
\hline No. & Question & Answer & $\begin{array}{c}\text { Percentage } \\
(\%)\end{array}$ \\
\hline & & $\begin{array}{c}\text { Strongly } \\
\text { Disagree }\end{array}$ & 2.9 \\
\hline
\end{tabular}

Source: Ministry of Religious Affairs Office, Banyumas Regency, 2017

Table 11 shows that the convenience for pilgrims to get services reach good ratings $(55.1 \%)$ but for those responders who marked neutral still represent $14.5 \%$. Accordingly, some applicants experience inconvenience with the service. Second, special attention with sincerity and full of responsibility from employees balanced between strongly agree and agree (45\% and 47\%) among the respondents, respectively.

Tabel 12 Satisfaction

\begin{tabular}{|c|c|c|c|}
\hline No. & Question & Answer & $\begin{array}{c}\text { Percentage } \\
(\%)\end{array}$ \\
\hline \multirow[t]{5}{*}{1} & \multirow{5}{*}{$\begin{array}{l}\text { Based on } \\
\text { experience, } \\
\text { pilgrims feel happy } \\
\text { to perform Hajj } \\
\text { through the MoRA, } \\
\text { Banyumas }\end{array}$} & $\begin{array}{l}\text { Strongly } \\
\text { Agree }\end{array}$ & 39.1 \\
\hline & & Agree & 46.3 \\
\hline & & Neutral & 14.5 \\
\hline & & Disagree & 0.0 \\
\hline & & $\begin{array}{l}\text { Strongly } \\
\text { Disagree }\end{array}$ & 0.0 \\
\hline \multirow[t]{5}{*}{2} & \multirow{5}{*}{$\begin{array}{l}\text { MoRA, Banyumas } \\
\text { has met the } \\
\text { expectations of the } \\
\text { worshipers/pilgrims }\end{array}$} & $\begin{array}{l}\text { Strongly } \\
\text { Agree }\end{array}$ & 40.5 \\
\hline & & Agree & 50.7 \\
\hline & & Neutral & 7.3 \\
\hline & & Disagree & 1.5 \\
\hline & & $\begin{array}{l}\text { Strongly } \\
\text { Disagree }\end{array}$ & 0.0 \\
\hline \multirow[t]{5}{*}{3} & \multirow{5}{*}{$\begin{array}{l}\text { Pilgrims believe } \\
\text { that the } \\
\text { implementation of } \\
\text { Hajj through the } \\
\text { MoRA, Banyumas } \\
\text { is a satisfying } \\
\text { experience }\end{array}$} & $\begin{array}{l}\text { Strongly } \\
\text { Agree }\end{array}$ & 37.7 \\
\hline & & Agree & 56.5 \\
\hline & & Neutral & 5.8 \\
\hline & & Disagree & 0.0 \\
\hline & & $\begin{array}{l}\text { Strongly } \\
\text { Disagree }\end{array}$ & 0.0 \\
\hline \multirow[t]{5}{*}{4} & \multirow{5}{*}{$\begin{array}{l}\text { Overall, pilgrims } \\
\text { believe, the MoRA, } \\
\text { Banyumas are } \\
\text { pleased with the } \\
\text { pilgrims when } \\
\text { performing Hajj }\end{array}$} & $\begin{array}{l}\text { Strongly } \\
\text { Agree }\end{array}$ & 52.2 \\
\hline & & Agree & 43.5 \\
\hline & & Neutral & 4.3 \\
\hline & & Disagree & 0.0 \\
\hline & & $\begin{array}{c}\text { Strongly } \\
\text { Disagree }\end{array}$ & 0.0 \\
\hline
\end{tabular}

Source: Ministry of Religious Affairs Office, Banyumas Regency, 2017

Table 12 indicates the satisfaction ratings from respondents divided into 4 categories. First, pilgrims feel happy to perform Hajj through the MoRA, Banyumas regency at $39.1 \%$ for strongly agree, $46.3 \%$ for agree and $14.5 \%$ who feel an unhappy experience. Second, the MoRA, Banyumas regency has met the expectations of the worshipers/pilgrims for most strongly agree and just agree, respectively at $40 \%, 51 \%$ 
followed by neutral $7.2 \%$, disagree $1.5 \%$ and strongly disagree $0 \%$. This rating indicates that most respondents have had their expectations met.

\subsection{Discussion}

The findings of this study indicate that the quality of service at Banyumas Ministry of Religion is well implemented and have a significant effect on increasing customers (pilgrims) satisfaction. Where assurance is the most significant influence greater than the other parts that serve as a strategy in this study. Then, followed by reliability, tangible, empathy in sequence influence customer satisfaction while responsiveness does not effect.

From the result of further analysis and based on the opinion of some respondents argued that there are still some things that still need to be corrected, among others, the existence of long queues that occur on the registrant so many who must be willing to wait long. Moreover, there are some registrans who argue that in the registration process some facilities are inadequate such as photo copy machine, less room, and still lack of parking in the office. In line, process of cancelation also takes a long step that could make a negative perception of service in the ministry of religion.

The above problems become an obstacle to the implementation of good service quality program, so the ministry of religion in Banyumas district need to fix all the deficiencies in an effort to increase customer satisfaction offered.

\section{Conclusion}

This study used a quantitative approach to grasp the primary data obtained from the charging views of the respondents. The original survey and analyses on the service quality with regards to customer (pilgrims) satisfaction as surveyed by the Ministry of Religion Affairs (MoRA) Banyumas Regency were examined. The author also presented how factors have been affected. From the formulation of the research problem proposed, the analysis of data has been carried out and the discussion as reviewed in the previous chapter, the author has drawn the following conclusions.

First, the result of research indicates that the respondents evaluated only four factors, namely, Tangible, Reliability, Assurance, and Empathy positively in terms of the applicant satisfaction. Therefore, the government could upgrade to Tangible, Reliability, Assurance, and Empathy because they are important during the period of Hajj registration. Thus, approximately $90 \%$ of respondents satisfies Empathy with regard to providing convenience, and almost $80 \%$ of respondents also satisfies with same service for applicant without error in response to Reliability. However, only $30 \%$ respondents feel neutral or assume that Hajj's room service is inadequate in supporting services because almost every day there is a queue of registrants.

Secondly, the research also proves out that from all factors, Empathy and Assurance have a significant influence on the applicant satisfaction. It means that MoRA needs to focus on politeness, trust and genuine concern to the applicants.

Third, there are some factors that relatively less satisfactory registrants such as the room organizers were less clean, comfortable and neat. The results indicates that MoRA as the sole Hajj operator could restore more comfortable, clean and neat rooms for the applicants.

\section{References}

Basyir, Abdul. (2018). BPS Terus Survey Kepuasan Jemaah Haji 2018. Available at https://haji.kemenag.go.id/v3/content/bps-terussurvey-kepuasan-jemaah-haji-2018 [Accessed on 9 September 2018].

Benkenstein M, Yavas U, Forberger D. (2003). Emotional and cognitive antecedents of customer satisfaction in leisure services: the case of Rostock Zoo. Journal of Hospitality and Leisure Marketing, Vol. 10, No. 3/4, pp.173184.

Creswell, J. W. (2014). Research Design: Qualitative, Quantitative and Mixed Methods Approaches (4th ed.). Thousand Oaks, CA: Sage.

Cronin, J. J., \& Taylor, S. A. (1992). Measuring service quality; a re-examination and Extension. The Journal of Marketing. Vol. 56, No.3, pp.5568.

Eid, Riyad. (2012). Towards a High-Quality Religious Tourism Marketing: The Case of Hajj Service in Saudi Arabia. Tourism Analysis, Vol. 17, No.1, pp. 509-522.

Grönroos, Christian. (1984). A Service Quality Model and its Marketing Implications. European Journal of Marketing. Vol. 18, Issue :4, pp. 3644.

Hafid, A. Rakhmat., \& Tahmir, S. Rifdan. (2016). Hajj Service Management at the Department of Religious Affairs in Gowa Regency. Mediterranean Journal of Social Sciences, Vol. 7, No 3 S1, pp.1-5.

Hasibuan, Malayu S.P. (2007). Manajemen Sumber Daya Manusia, Cetakan 9. Jakarta: PT. Bumi Aksara. 
Kotler, P., \& Keller, K.L. (2007). Manajemen Pemasaran. Jilid 1 dan 2. Jakarta: Penerbit PT Indeks.

Ministry of Religious Affairs Office, Banyumas Regency. (2017). From Profil Kantor Kementerian Agama Kabupaten Banyumas 2016. Banyumas: Ministry of Religious Affairs Office, Banyumas Regency.

Jabnoun, Naceur. (2003). Development of Hajqual: A marketing research tool to measure Hajj service quality. Journal of International Business and Entrepreneurship Development. Vol. 1, No. 1 (Special Issue), pp.22-28.

Parasuraman, A., Zeithaml, V. A., and Berry, L. L. (1988). SERVQUAL: A multiple-item scale for measuring consumer perceptions of service quality. Journal of Retailing. Vol. 64, No. 1, pp.12-40.

Ratminto., \& Atik Winarsih. (2006). Manajemen Pelayanan Publik: Pengembangan Konseptual, Penerapan Citizen's Charter dan Standar Pelayanan Minimal. Yogyakarta: Penerbit Pustaka Pelajar. 